\title{
Multilocus analysis of the catfish family Trichomycteridae (Teleostei: Ostariophysi: Siluriformes) supporting a monophyletic Trichomycterinae
}

\author{
Luz E. Ochoa $^{\mathrm{a}, *}$, Fabio F. Roxo ${ }^{\mathrm{a}}$, Carlos DoNascimiento ${ }^{\mathrm{b}}$, Mark H. Sabaj ${ }^{\mathrm{c}}$, Aléssio Datovo ${ }^{\mathrm{d}}$, Michael Alfaro ${ }^{\mathrm{e}}$, \\ Claudio Oliveira ${ }^{a}$ \\ a Departamento de Morfologia, Instituto de Biociências, UNESP - Universidade Estadual Paulista “Julio de Mesquita Filho”, Botucatu, SP, Brazil \\ ${ }^{\mathrm{b}}$ Instituto de Investigación de Recursos Biológicos Alexander von Humboldt, Villa de Leiva, Boyacá, Colombia \\ ${ }^{\mathrm{c}}$ The Academy of Natural Sciences of Drexel University - ANSP, Philadelphia, PA, USA \\ ${ }^{\mathrm{d}}$ Museu de Zoologia da Universidade de São Paulo - MZUSP, São Paulo, SP, Brazil \\ e Department of Ecology and Evolutionary Biology, University of California, Los Angeles, CA, USA
}

\section{A R T I C L E I N F O}

\section{Article history:}

Received 28 April 2017

Revised 4 July 2017

Accepted 7 July 2017

Available online 14 July 2017

\section{Keywords:}

Freshwater fishes

Molecular phylogeny

Neotropical region

Systematics

\begin{abstract}
A B S T R A C T
Trichomycteridae is the second most diverse family of the order Siluriformes, its members are widely distributed through the freshwaters of Central and South America, exhibiting an exceptional ecological and phenotypic disparity. The most diverse subfamily, Trichomycterinae, represented mainly by the genus Trichomycterus, historically has been recognized as non-monophyletic and various characters used to unite or divide its constituents are repeatedly called into question. No comprehensive molecular phylogenetic hypothesis regarding relationships of trichomycterids has been produced, and the present study is the first extensive phylogeny for the family Trichomycteridae, based on a multilocus dataset of three mitochondrial loci and two nuclear markers ( $3284 \mathrm{bp}$ total). Our analysis has the most comprehensive taxon-sampling of the Trichomycteridae published so far, including members of all subfamilies and a vast representation of Trichomycterus diversity. Analysis of these data showed a phylogenetic hypothesis with broad agreement between the Bayesian (BI) and maximum-likelihood (ML) trees. The results provided overwhelming support for the monophyletic status of Copionodontinae, Stegophilinae, Trichomycterinae, and Vandelliinae, but not Sarcoglanidinae and Glanapteryginae. A major feature of our results is the support to the current conceptualization of Trichomycterinae, which includes Ituglanis and Scleronema and excludes the "Trichomycterus" hasemani group. Divergence time analysis based on DNA substitution rates suggested a Lower Cretaceous origin of the family and the divergence events at subfamilial level shaped by Paleogene events in the geohistory of South America. This hypothesis lays a foundation for an array of future studies of evolution and biogeography of the family.
\end{abstract}

(c) 2017 Elsevier Inc. All rights reserved.

\section{Introduction}

Siluriformes (catfishes) is the third most speciose order of extant fishes with more than 3700 valid species (Eschmeyer et al., 2017) and widely distributed in freshwaters of all continents (except Antarctica), and estuarine and marine habitats of continental shelves (de Pinna, 1998). Catfishes present an unparalleled diversity of morphological, ecological, and behavioral traits (Adriaens et al., 2010). Within the order, Trichomycteridae is the second most diverse family and includes species commonly known as pencil and parasitic catfishes. With about 300 valid species

\footnotetext{
* Corresponding author.

E-mail address: luzeocho@gmail.com (L.E. Ochoa).
}

(Eschmeyer et al., 2017), trichomycterids are currently divided into eight subfamilies (Copionodontinae, Glanapteryginae, Sarcoglanidinae, Stegophilinae, Trichogeninae, Trichomycterinae, Tridentinae, and Vandelliinae) and 41 genera (Eschmeyer et al., 2017). Members of the family are distributed through continental freshwaters from Costa Rica to Patagonia (de Pinna and Wosiacki, 2003), with a single species occurring in the small island Gorgona island, off the Pacific coast in Colombia (Fernández and Schaefer, 2005). Species of Trichomycteridae exhibit a remarkable variety of feeding strategies, including semiparasitic hematophagy (Vandelliinae), lepidophagy and mucophagy (Stegophilinae), and occupy a wide range of habitats from subterranean waters to Andean streams and lakes up to $4500 \mathrm{~m}$ asl (Arratia and Menu-Marque, 1984; de Pinna and Wosiacki, 2003; Rizzato et al., 2011). 
Eigenmann (1918) proposed an evolutionary tree depicting relationships among the 18 genera of trichomycterid genera known at the time, including Nematogenys as the most basal taxon. Baskin (1973) was the first to provide explicit cladistic support for the monophyly of the Trichomycteridae and divided all then-known trichomycterids into the Trichomycterinae-group (Glanapteryginae, Sarcoglanidinae and Trichomycterinae) and the Vandelliinae-group (Stegophilinae, Tridentinae and Vandelliinae). Later discoveries added a clade composed of two subfamilies, Copionodontinae and Trichogeninae, as the sister to all other trichomycterids (de Pinna, 1992, 1998; Datovo and Bockmann, 2010). Costa and Bockmann (1994) realigned the Glanapteryginae and Sarcoglanidinae with Baskin's Vandelliinaegroup to form the so-called TSVSG clade. Subsequent studies upheld the TSVSG clade with both morphological (Datovo and Bockmann, 2010) and molecular (Fernández and Schaefer, 2009) evidence.

The monophyly of seven of the eight subfamilies of the Trichomycteridae is well supported by morphology: Copionodontinae (de Pinna, 1992), Glanapteryginae (de Pinna, 1989b), Sarcoglanidinae (de Pinna, 1989a; Costa 1994; Costa and Bockmann, 1994), Stegophilinae (Baskin, 1973; de Pinna and Britski, 1991; DoNascimiento, 2015), Trichogeninae (de Pinna et al., 2010), Tridentinae (Baskin, 1973) and Vandelliinae (Baskin, 1973; de Pinna, 1998) (see Fig. 1).

Trichomycterinae is the most speciose subfamily of the Trichomycteridae with about 200 species distributed in eight genera: Bullockia (1 species), Eremophilus (1), Hatcheria (1), Ituglanis (26), Rhizosomichthys (1), Scleronema (3), Silvinichthys (7), and Trichomycterus (160+) (Eschmeyer et al., 2017). The monophyly of this subfamily remains ambiguous, as well as the synapomorphies repeatedly called into question (de Pinna, 1989a; Datovo and Bockmann, 2010; García-Melo et al., 2016). The main obstacle to understand the relationships within Trichomycteridae is the most diverse genus, Trichomycterus, which has a complex taxonomic history and is a non-monophyletic assemblage that basically includes those species lacking the diagnostic characters of other trichomycterine genera (Baskin, 1973; de Pinna, 1989a, 1998; Datovo and Bockmann, 2010). Despite the description of more than 70 new species in the last two decades (Eschmeyer et al., 2017), Trichomycterus still includes a large number of undescribed taxa. The limits and phyletic status of the whole Trichomycterinae is also controversial. While most studies agree with the exclusion of the so-called "Trichomycterus" hasemani group from the subfamily, alternative hypotheses of placement and inclusion or not of Scleronema and Ituglanis have been proposed (de Pinna, 1989a; Arratia, 1990; Costa and Bockmann, 1993, 1994; Datovo and Bockmann, 2010; Dutra et al., 2012; DoNascimiento, 2015). All these issues contribute to make the phylogenetic revision of the Trichomycterinae one of the greatest challenges of catfish systematics.

Although recent work using morphology and molecules has shed much light on the phylogenetic relationships of the Trichomycteridae, disagreements persist, especially on the monophyly and composition of the two key taxa that concentrate the vast majority of the family diversity: Trichomycterinae and Trichomycterus. We present here a multilocus analysis of the Trichomycteridae based on the most comprehensive taxon sampling to date that includes members of all subfamilies and a vast representation of Trichomycterus diversity. Also, a time-calibrated molecular tree analysis was performed to hypothesize diversification dates relative to the evolutionary history of this important Neotropical lineage and key to our understanding of catfish relationships.

\section{Material and methods}

\subsection{Taxon sampling}

Analysis was based on a total of 94 terminals representing 18 genera of all eight subfamilies of the Trichomycteridae (Copionodontinae, Glanapteryginae, Sarcoglanidinae, Stegophilinae, Trichogeninae, Trichomycterinae, Tridentinae, and Vandelliinae) plus Nematogenys inermis. We included samples of cis and trans-Andean species of Trichomycterus, the former better represented by species from the Atlantic coast of Brazil. Nematogenys inermis, the sole extant member of the Nematogenyidae, was chosen as the outgroup as this taxon is often hypothesized to be the sister group of the Trichomycteridae (Eigenmann, 1918, 1927; de Pinna, 1992, 1998) and is widely recognized as retaining the most primitive morphology within Loricarioidei (Eigenmann, 1918, 1927; Baskin, 1973; Arratia and Huaquín, 1995; de Pinna, 1992, 1998). Data sequences were obtained from tissue samples collected by the authors. Vouchers of samples are deposited in the ichthyological collections of the Academy of Natural Sciences of Drexel University, USA (ANSP) and the Laboratório de Biologia e Genética de Peixes, Botucatu, Brazil (LBP). Taxonomic identification of voucher specimens was validated by direct examination. Catalog numbers of vouchers and tissues used in this study are given in Supplementary Table S1.

\subsection{DNA extraction and sequencing}

DNA was extracted from tissues preserved in 95\% EtOH using the DNeasy Tissue kit (Qiagen Inc.; http://www.qiagen.com) following the manufacturer's instructions. Partial sequences of three mitochondrial (16S rRNA, cytochrome C oxidase subunit I - coi and cytochrome B - cytb) and two nuclear (myosin heavy chain 6 , cardiac muscle, alpha gene - myh6 and recombination activating gene 2 - rag2) genes were amplified by polymerase chain reaction (PCR) with the primers described in Table S2 (Kocher et al., 1989; Irwin et al., 1991; Palumbi, 1996; Lovejoy and Collette, 2001; Ward et al., 2005; Li et al., 2007; Oliveira et al., 2011). Amplifications were performed in a total volume of $12.5 \mu \mathrm{l}$ with $1.25 \mu \mathrm{l}$ of $10 \mathrm{X}$ buffer $(10 \mathrm{mM}$ Tris- $\mathrm{HCl}+15 \mathrm{mM} \mathrm{MgCl} 2), 0.5 \mu \mathrm{ldNTs}$ ( $200 \mathrm{nM}$ of each), $0.5 \mu$ l each $5 \mathrm{mM}$ primer, $0.05 \mu$ l Platinum ${ }^{\circledR}$ Taq Polymerase (Invitrogen), $1 \mu$ l genomic DNA (10-50 ng), and $8.7 \mu$ lddH2O. The thermo-cycler profile consisted of an initial denaturation ( $4 \mathrm{~min}$ at $95^{\circ} \mathrm{C}$ ) followed by 30 cycles of chain denaturation $\left(30 \mathrm{~s}\right.$ at $\left.95^{\circ} \mathrm{C}\right)$, primer hybridization $\left(30-60 \mathrm{~s}\right.$ at $52-54^{\circ} \mathrm{C}$ ) and nucleotide extension $\left(30-60 \mathrm{~s}\right.$ at $\left.72{ }^{\circ} \mathrm{C}\right)$. All PCR products were first visually identified on $1 \%$ agarose gel and then purified using ExoSap-IT ${ }^{\circledR}$ (USB Corporation) following manufacturer instructions. The purified PCR products were sequenced using the "Big DyeTM Terminator v 3.1 Cycle Sequencing Ready Reaction Kit" (Applied Biosystems), purified again by ethanol precipitation and loaded onto an automatic sequencer 3130-Genetic Analyzer (Applied Biosystems) in the Instituto de Biociências, Universidade Estadual Paulista UNESP, Botucatu, São Paulo, Brazil. All sequences were read twice (forward and reverse).

\subsection{Sequences assembly and alignment}

The consensus sequences for each individual gene were assembled from chromatograms for forward and reverse sequences using Geneious software v7.1.7 (Biomatters Ltd., Auckland, New Zealand). Initially we built matrixes for every gene and they were independently aligned using the MUSCLE algorithm under default parameters (Edgar, 2004). The alignments were inspected by eye 
A
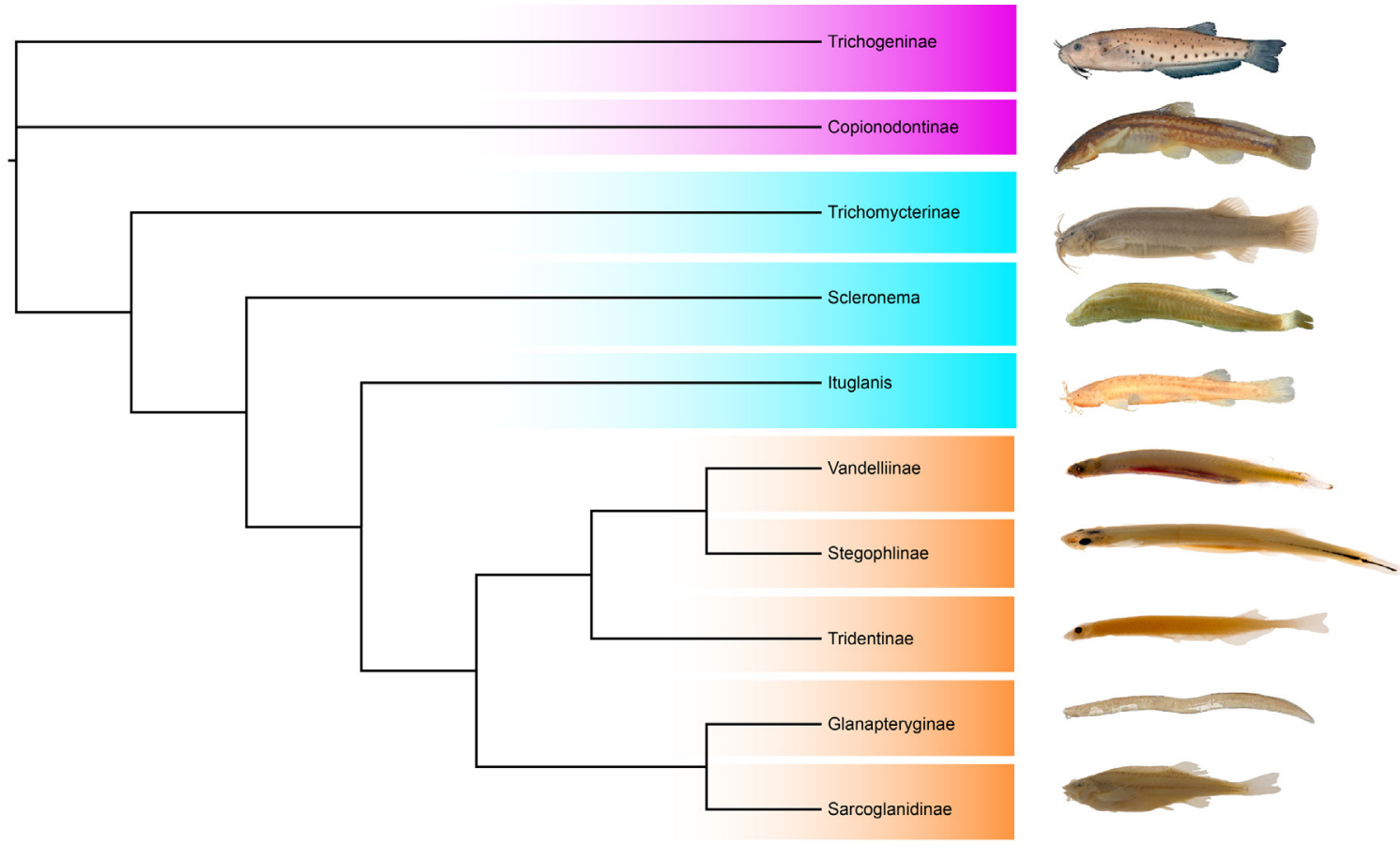

B
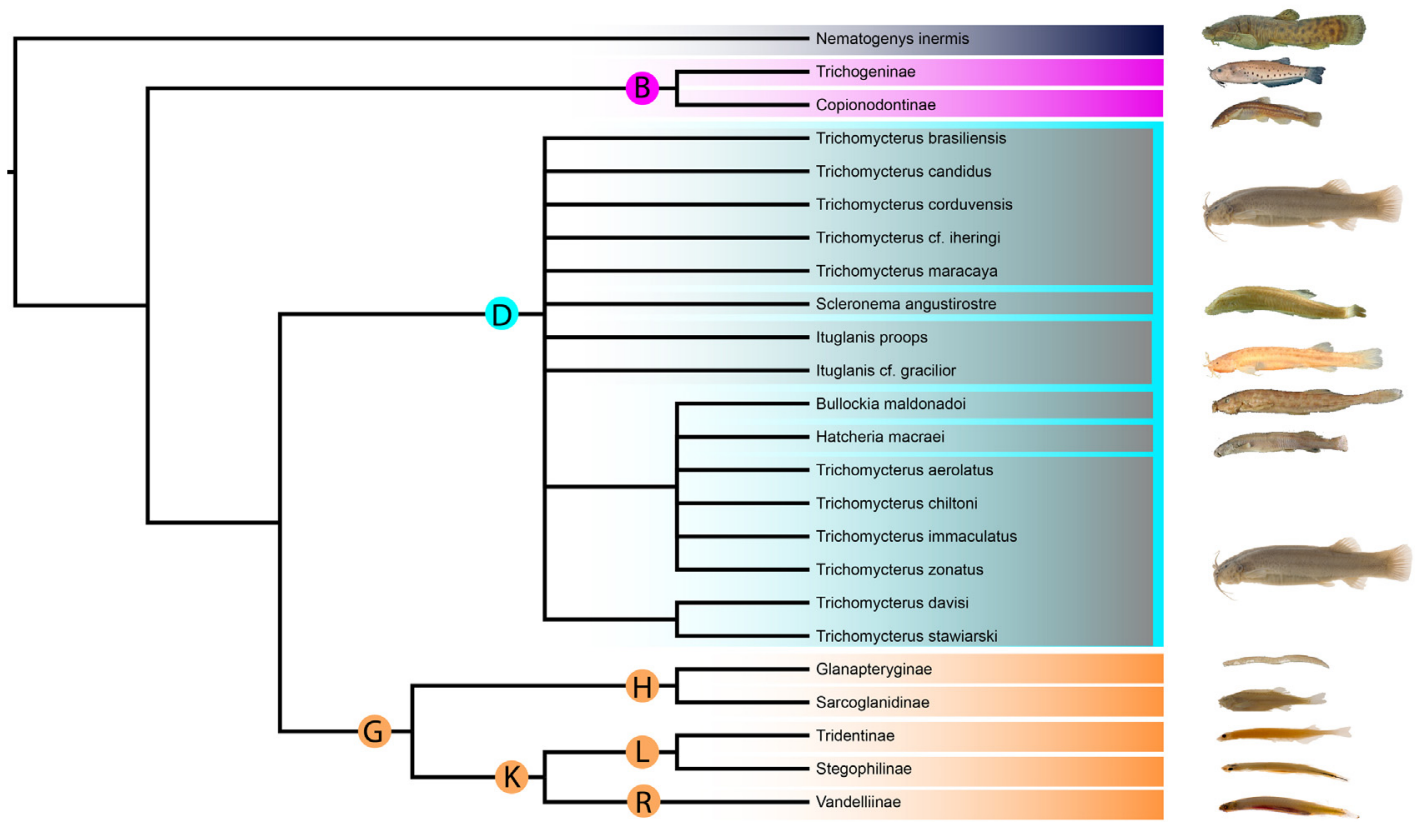

Fig. 1. Previous phylogenetic hypothesis for the family Trichomycteridae based in A) de Pinna (1998); and B Datovo and Bockmann (2010).

for any obvious misalignments that were then corrected. To detect potential cases of sequencing errors due to contamination or paralogy, the alignment for each gene was analyzed by maximum likelihood (ML) and rapid bootstrapping using RAxML (Stamatakis, 2006). Sequences that were found misplaced in relation to putative congeneric or conspecific specimens in the resulting gene tree were re-sequenced or eliminated from subsequent analysis. To evaluate the occurrence of substitution saturation, we used the index of substitution saturation (Iss) test as described by Xia et al. (2003) and Xia and Lemey (2009) implemented in the software Dambe 5.3.38 (Xia, 2013). Only unambiguously alignable regions were included; hypervariable, unalignable loop regions were excluded. Alignments of all loci were concatenated into a single matrix consisting of 3284 bp of the 93 terminals plus the outgroup Nematogenys inermis. Each gene except 16S was partitioned by gene and codon positions to determine codon-specific models of molecular evolution in PartitionFinder v1.1.1 (Lanfear et al., 2012). The best models were chosen under the best value for the Bayesian Information Criterion (BIC) index as detailed in Table 2.

\subsection{Phylogenetic analysis}

The phylogenetic hypotheses were inferred from two reconstruction methods using the partitioned data. First, Bayesian Inference (BI) was conducted in MrBayes v3.1.2 (Huelsenbeck and 
Ronquist, 2001; Ronquist and Huelsenbeck, 2003) via the CIPRES web portal (Miller et al., 2010). MrBayes was programmed to run for 15 million generations, with two runs of four independent MCMC chains (three heated, one cold), sampling one tree every one thousand generation. After a graphical analysis of the evolution of the likelihood scores, and checking for the stationarity of all model parameters, the first 4 million generations (25\%) were discarded as burn-in. The remaining trees were used to calculate the consensus tree. The maximum likelihood (ML) phylogenetic reconstructions were performed using RAxML (Stamatakis, 2006) via command line with the "a" algorithm for rapid bootstrapping analysis (ML search and bootstrapping) in one step and specifying a random number seed for the parsimony estimation. The number of alternative runs was 100 and the analyses were performed under the model GTR + G.

Measures of branch support are given as posterior probability (P) and non-parametric bootstrap percentage (BS) separated by a common slash (/); asterisks represent values $<0.5$ (P) or $<50 \%$ (BS). A topology test was performed to evaluate the degree of support for the resulting molecular phylogeny versus the previously published morphological hypothesis. We compared the ML scores of an unconstrained tree (our resulting topology) with a constrained tree enforcing the interfamilial relationships proposed by Datovo and Bockmann (2010). A Constraint tree was constructed in Mesquite (Maddison and Maddison, 2011), and the confidence in the comparison of ML scores for every topology was evaluated with the Shimodaira-Hasegawa test (SH) (Shimodaira and Hasegawa, 1999), Kishino and Hasegawa test (KH) and Unbiased test (AU) using the CONSEL package.

\subsection{Time calibrated tree}

The uncorrelated relaxed molecular clock (lognormal) was estimated using BEAST v.1.7 (Drummond et al., 2012) and all clade-age inferences are presented as 95\% highest posterior density (HPD). We included two calibration points to constrain divergence dates for the 93 species of trichomycterids included in our phylogenetic tree. The first calibration point was implemented in the root of the phylogeny for the origin of Trichomycteridae about 106 million years ago (Mya) as estimated by Betancur-R et al. (2015). We implemented a normally distributed prior with mean of 106 and standard deviation of seven. The search was conducted among the interval of 92.28-119.7 Mya using the lower and upper quantiles of $2.5 \%$, respectively.

The second calibration point was implemented using a lognormal prior offset and mean of 4.5 Mya and standard deviation of 1.5 for the origin of the subfamily Trichomycterinae. The only known fossil for the family Trichomycteridae was described from the Monte Hermoso Formation in Argentina by Bogan and Agnolin (2009). Based on biostratigraphy, Tomassini et al. (2013) estimated the upper and lower boundaries of the Monte Hermoso Formation to be $4.5 / 5$ and 5.3 Mya, respectively. The search for the second calibration point was conducted within the interval of 4.432.13 Mya using the lower and upper quantiles of $2.5 \%$, respectively. We used a macroevolutionary Birth-Death model for the diversification likelihood values and a starting tree obtained from the Bayesian inference. The analyses were conducted under different models of molecular evolution for each partition of the data matrix as evaluated by the software PartitionFinder v1.1.1 (Lanfear et al., 2012) (Table S3). The analysis was run for 10 million generations and sampled every 1000 generation. Stationarity and sufficient mixing of parameters (ESS.200) were checked using Tracer v1.5 (Rambaut and Drummond, 2007a). A consensus tree was built using TreeAnnotator v1.8.2 (Rambaut and Drummond, 2007b).

\section{Results}

\subsection{Overall aspects of the matrix}

The concatenated matrix of the three mitochondrial and two nuclear genes consist of $3284 \mathrm{bp}$ after alignment (466 for 16S; 524 for coi; 859 for cytb; 544 for myh6; 891 for rag2). In the total matrix, 1278 sites were variable, 1010 were parsimony informative and 2008 were invariant (I). The nucleotide composition of the concatenated matrix was of $28.1 \%$ thymine, $22.6 \%$ cytosine, $25.5 \%$ adenine and $23.7 \%$ guanine.

The Iss index indicated no saturation considering that the Iss.c value is greater than the Iss. For each gene, the number and percentage of sequences obtained, size in base pairs (bp), number of variable and invariant sites (I), number of informative characters under parsimony, nucleotide frequency and overall mean genetic distance (S.E.) are presented in Table 1 . The matrix was partitioned by gene (except $16 \mathrm{~S}$ ) and coding positions, into 13 sections. The partition scheme consisted of eight subsets and 250 parameters, and the evolutionary model for each gene and codon position evaluated in PartitionFinder are showed in Table 2.

\subsection{Phylogenetic hypothesis}

The tree topologies estimated by the BI and ML analyses were similar with exception of the relationships of Eremophilus mutisii that in ML analysis was hypothesized as an independent lineage with a low statistical support. Although sampling at genus level was incomplete, statistical support for the monophyly of four subfamilies was high: $\mathrm{P}=1.00, \mathrm{BS}=100$ for Copionodontinae ( 2 of 2 genera sampled; clade $\mathrm{B}) ; \mathrm{P}=0.99, \mathrm{BS}=23$ for Trichomycterinae ( 5 of 8 genera; clade D); $\mathrm{P}=1.00, \mathrm{BS}=86$ for Stegophilinae ( 4 of 11 genera, clade TSVSG); and $P=1.00, B S=100$ for Vandelliinae (2 of 4 genera, clade TSVSG) (Fig. 2). The monophyly of the Trichogeninae ( 1 genus), Tridentinae ( 4 genera) and Glanapteryginae (4 genera) could not be tested due to the low taxonomic representation that included one genus from each subfamily, Trichogenes longipinnis, Tridens sp $\mathrm{n} 2$ and two species of Listrura, respectively. Our results did not support the monophyly of Sarcoglanidinae (6 genera) based on the two genera analyzed (Sarcoglanis and Stauroglanis).

The sister group relationship between Trichogenes and Copionodontinae (Fig. 2; $\mathrm{P}=1.00, \mathrm{BS}=98$, clade $\mathrm{B}$ ) is strongly supported (Fig. 2), as well as the placement of this clade as sister to remaining trichomycterids (Fig. $2 ; \mathrm{P}=1.00, \mathrm{BS}=100$ ). The TSVSG clade was recovered as monophyletic, but with relatively low statistical support (Fig. 2; $\mathrm{P}=0.58, \mathrm{BS}=57$ ). Within the TSVSG clade, the clade composed by two glanapterygine species, Listrura camposi and $L$. picinguabae is the first group to diverge. The two genera of sarcoglanidines analyzed, the monotypic Sarcoglanis and Stauroglanis, were not found closely related to each other within the TSVSG clade. Sarcoglanis grouped with "Trichomycterus" hasemani, Tridens melanops (Tridentinae) and members of the Stegophilinae, whereas Stauroglanis grouped with two genera of the Vandelliinae (Paravandellia and Vandellia).

Our analyses supported the monophyly of the Trichomycterinae exclusive of "Trichomycterus" hasemani with high BI support (Fig. 2; $\mathrm{P}=0.99$, BS < 50). Species of five genera (Bullockia, Eremophilus, Ituglanis, Scleronema and Trichomycterus) constitute a large "Clade D" (sensu Datovo and Bockmann, 2010) divided into two subclades and six main lineages. The first clade to diverge within subclade $\mathrm{D} 1+\mathrm{D} 2+\mathrm{E}+\mathrm{D} 3$ (D1, $\mathrm{P}=0.54, \mathrm{BS}<50$; Fig. 2) clusters three trans-Andean taxa, the troglomorphic Trichomycterus sandovali (Magdalena basin), T. punctulatus (Pacific versant of Peru), and Eremophilus mutisii (Magdalena basin), with a species from the Meta 
Table 1

Characteristics of the matrix for each gene and total matrix.

\begin{tabular}{|c|c|c|c|c|c|c|}
\hline & \multicolumn{3}{|l|}{ Mitochondrial } & \multicolumn{2}{|l|}{ Nuclear } & \multirow[b]{2}{*}{ Concatenated matrix } \\
\hline & $16 \mathrm{~S}$ & $\mathrm{COI}$ & Cytb & Myh6 & Rag2 & \\
\hline Total number of sequences & 92 & 89 & 66 & 86 & 62 & 93 \\
\hline Base-pairs (bp) after alignment & 466 & 524 & 859 & 544 & 891 & 3284 \\
\hline Number of variable sites & 139 & 216 & 403 & 193 & 329 & 1278 \\
\hline Number of invariants (I) sites & 327 & 308 & 456 & 351 & 566 & 2006 \\
\hline $\begin{array}{l}\text { Number of informative characters under parsimony } \\
\text { Nucleotide frequency }\end{array}$ & 95 & 205 & 360 & 140 & 214 & 1010 \\
\hline A & 22.0 & 25.0 & 28.0 & 25.4 & 26.4 & 25.5 \\
\hline C & 24.2 & 28.2 & 15.2 & 22.3 & 24.2 & 22.6 \\
\hline G & 23.7 & 17.4 & 29.0 & 22.2 & 25.2 & 23.7 \\
\hline $\mathrm{T}$ & 30.1 & 29.4 & 27.7 & 30.1 & 24.2 & 28.1 \\
\hline Overall mean genetic distance (S.E.) & $0.042 \pm 0.004$ & $0.147 \pm 0.009$ & $0.151 \pm 0.007$ & $0.046 \pm 0.004$ & $0.050 \pm 0.003$ & $0.090 \pm 0.003$ \\
\hline
\end{tabular}

Table 2

Evolutionary models by gene and codon position found in PartitionFinder.

\begin{tabular}{|c|c|c|c|}
\hline Subset & Scheme of partition & Partitions & Best-fit model \\
\hline 1 & $16 S$ & $1-466$ & $\mathrm{GTR}+\mathrm{I}+\mathrm{G}$ \\
\hline \multirow[t]{2}{*}{2} & COI 1st position & $467-990 \backslash 3$ & $\mathrm{~K} 81+\mathrm{I}+\mathrm{G}$ \\
\hline & Cytb 1st position & $991-1849 \backslash 3$ & \\
\hline 3 & COI 2nd position & $468-990 \backslash 3$ & $\mathrm{~F} 81+\mathrm{I}$ \\
\hline 4 & COI 3rd position & $469-990 \backslash 3$ & $\mathrm{GTR}+\mathrm{I}+\mathrm{G}$ \\
\hline 5 & Cytb 2nd position & $992-1849 \backslash 3$ & $\mathrm{GTR}+\mathrm{G}$ \\
\hline \multirow[t]{2}{*}{6} & Cytb 3rd position & $993-1849 \backslash 3$ & $\mathrm{HKY}+\mathrm{I}+\mathrm{G}$ \\
\hline & Myh6 2nd position & $1851-2393 \backslash 3$ & \\
\hline \multirow[t]{2}{*}{7} & Myh6 1st position & $1850-2393 \backslash 3$ & TVMEF + G \\
\hline & Rag2 1st position & $2394-3284 \backslash 3$ & \\
\hline \multirow[t]{3}{*}{8} & Myh6 3rd position & $1852-2393 \backslash 3$ & TRNEF + I + G \\
\hline & Rag2 2nd position & $2395-3284 \backslash 3$ & \\
\hline & Rag2 3rd position & $2396-3284 \backslash 3$ & \\
\hline \multicolumn{2}{|c|}{$\ln L:-36058.22$} & \multicolumn{2}{|c|}{ Number of parameters: 250} \\
\hline
\end{tabular}

River (Orinoco basin), Trichomycterus cf. knerii. These relationships were different in ML analysis, with E. mutisii as an independent lineage with a low support (BS $<50)$.

Clade D2 (Fig. 2; $\mathrm{P}=1.00, \mathrm{BS}<50$ ) groups species of Trichomycterus from the Magdalena basin (T. banneaui, $T$. cachiraensis, $T$. ruitoquensis, $T$. straminius, Trichomycterus cf. trasandianus) with $T$ cf. guianensis (Essequibo basin, Guyana) and Trichomycterus aff. spilosoma (Pacific versant of Ecuador). The third clade (Fig. 2; P = 0.94, $\mathrm{BS}=86$ ) partially corresponds to "Clade E" of Datovo and Bockmann (2010) and grouped two trans-Andean species from Chile, Bullockia maldonadoi and T. areolatus, as sister to an undescribed cis-Andean species, Trichomycterus sp. 2, from upper Paraguay River basin. Clade D3 (Fig. 2; P=1.00, BS =100) corresponds to analyzed species of Ituglanis from the Amazon basin (Jari, Madeira, Tapajós, and Tocantins Rivers), La Plata system (Paraguay and Paraná Rivers) and smaller Atlantic coastal drainages of southern (Jacuí and Ribeira de Iguape Rivers) and southeastern (Macabú River) Brazil.

The sister group relationship between clades D4 and D5 is strongly supported (Fig. 2; $\mathrm{P}=0.99, \mathrm{BS}=87$ ) and ties Scleronema (lower La Plata system and Atlantic coastal drainages in Southern Brazil and Uruguay) with species of Trichomycterus distributed in Atlantic coastal drainages from the São Francisco River in the north to the Paraná and Uruguay rivers in the south. Clade D4 has high nodal support in both the $\mathrm{BI}$ and $\mathrm{ML}$ analysis (Fig. 2; $\mathrm{P}=0.99$, $\mathrm{BS}=100$ ) and places the clade formed by Scleronema minutum and S. cf. angustirostre (from tributaries of Laguna dos Patos system) sister of a group of species of Trichomycterus distributed in the Atlantic coastal drainages, including the upper São Francisco basin, Itapocu, Jacuí, Ribeira de Iguape, Uruguay, and tributaries to the Paraná drainages (Paranapanema and Tietê Rivers).

Clade D5 (Fig. 2; P = 0.99, BS = 100) also includes species of Trichomycterus from Atlantic coastal drainages of eastern and south- ern Brazil. In this clade, the first group to diverge includes $T$. itatiayae (Paraiba do Sul, River), T. piratymbara (Grande-Paraná, River system), and T. reinhardti (Paraopeba-São Francisco River system). The second group to diverge includes T. florensis (Paraiba do Sul River) sister to specimens of $T$. nigroauratus from the same basin and the Grande River (Paraná basin). The third group to diverge is represented by $T$. albinotatus (Paraiba do Sul River), $T$. alternatus and T. immaculatus (Doce River), and two species of Trichomycterus from the Jequitinhonha River, $T$. pradensis and $T$. cf. mimosensis. The third group is sister to a clade partially corresponding to the so-called $T$. brasiliensis complex by Barbosa and Costa (2010), including species distributed in the Grande River (Paraná basin) and upper São Francisco basin.

Our topology test using a constraint tree for subfamilial relationships proposed by Datovo and Bockmann (2010), resulted in a hypothesis with low likelihood value (Table 3 ). However, the difference between the constraint tree and the herein proposed tree was minimal, and consequently, the topology test failed to reject the null hypothesis of morphology-based relationships within Trichomycteridae.

\subsection{Time calibrated tree}

The mean substitution rate for the dataset estimated in BEAST was $0.0163 \%$ per My. The Trichomycteridae was estimated to have originated near the end of the Lower Cretaceous about 103.2 Mya (54.5-109.7 Mya, 95\% HPD) and around the time of the continental separation between Africa and South America (ca. 100 Mya; Torsvik et al., 2008). The first split is estimated during the Middle of the Upper Cretaceous diverging in two larger groups, Copionodontinae + Trichogeninae and the clade of the remaining trichomycterids. The next split is estimated at $66.8 \mathrm{Mya}$, just before the K-T boundary, and established the ancestral of the TSVSG clade and Trichomycterinae. Within the TSVSG clade, the oldest glanapterygine genus Listrura was originated in the Paleocene and the remaining subfamilies arose in the Eocene (Sarcoglanidinae, Tridentinae, Vandelliinae) and Oligocene (Stegophilinae). Oligocene diversification within Trichomycterinae established the three major clades composed mostly of trans-Andean taxa (D1-2, E), and the three remaining strictly cis-Andean clades (D3-5). Much of the diversification within those major clades appears to have occurred during the Miocene (Fig. 3).

\section{Discussion}

\subsection{Phylogenetic relationships among Trichomycteridae subfamilies}

The molecular phylogenetic hypothesis supported the monophyletic status of the Copionodontinae, Stegophilinae, Trichomycterinae, and Vandelliinae, but not Sarcoglanidinae. The current 


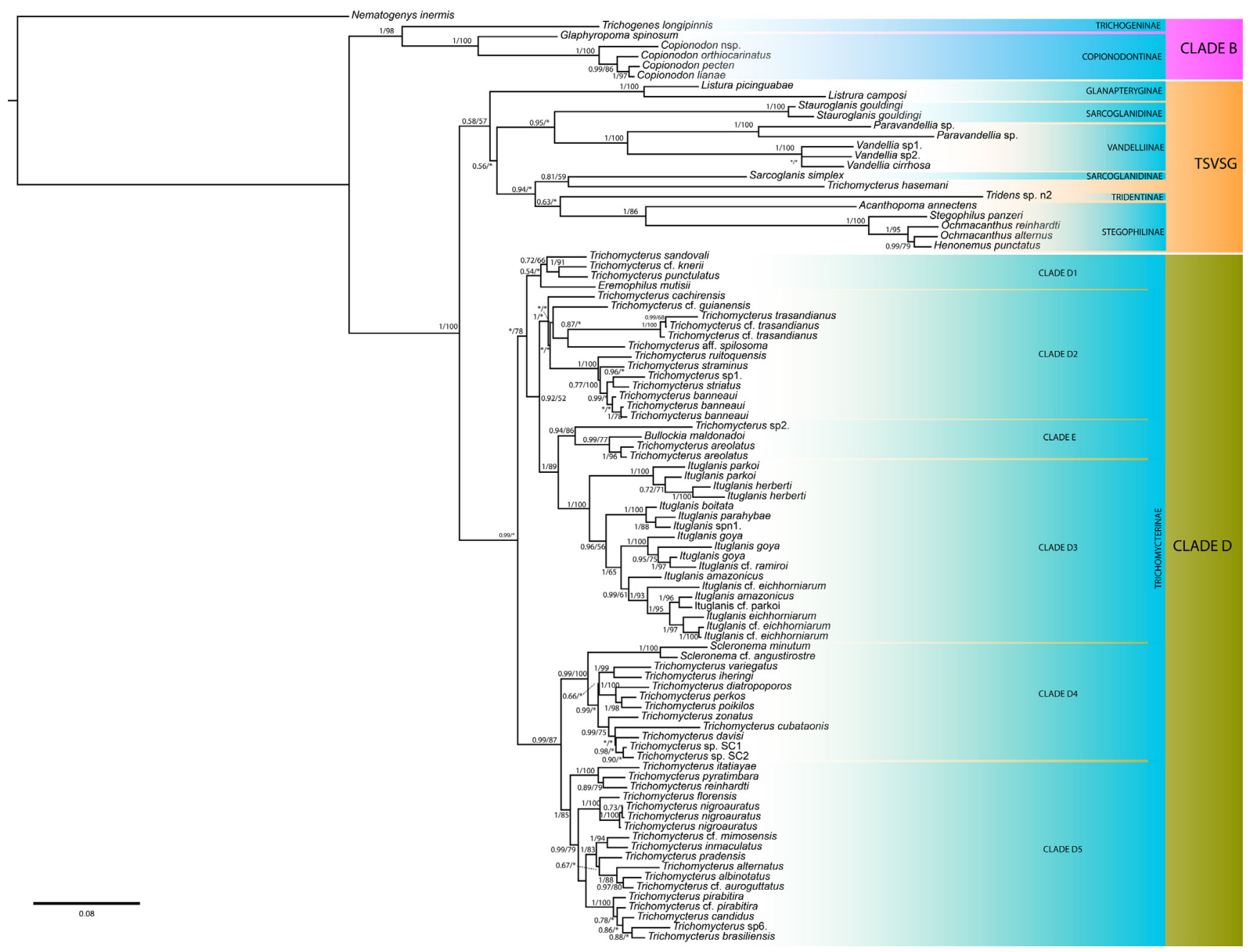

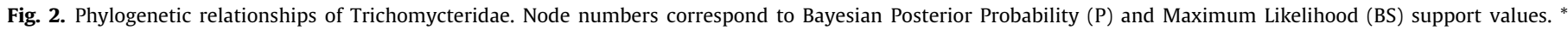
indicate $\mathrm{P}$ and $\mathrm{BS}$ values $<0.50$ and $<50$ respectively.

Table 3

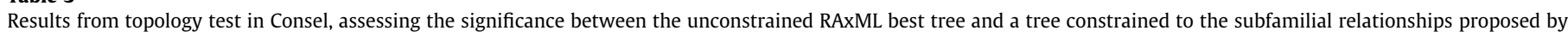
Datovo and Bockmann (2010).

\begin{tabular}{|c|c|c|c|c|c|c|}
\hline Analysis & $\operatorname{lnL}$ score & Rank & Delta $\ln L$ & AU- P value & SH- P value & $\mathrm{KH}$ - P value \\
\hline Unconstrained tree & -36106.04 & 1 & -26.6 & 0.976 & 0.964 & 0.964 \\
\hline Constrained tree & -36133.43 & 2 & 26.6 & 0.024 & 0.036 & 0.036 \\
\hline
\end{tabular}

conceptualization of the Trichomycterinae, which includes Ituglanis and Scleronema but excludes the "Trichomycterus" hasemani group (Datovo and Bockmann, 2010; see item 4.2 below), was confirmed as a monophyletic unit with high support both in both, BI and ML analyses. The topology corroborated the most recent morphological tree of the family (Datovo and Bockmann, 2010) in several important ways: Copionodontinae and Trichogenes form a monophyletic group that is sister to remaining trichomycterids, and this latter clade is divided into two main linages, the TSVSG clade and Trichomycterinae. Internal relationships for the TSVSG clade, however, differs in some significant aspects from the traditional phylogenetic hypotheses, mainly due to the nonmonophyly of the Sarcoglanidinae, although not all genera herein represented. The systematic positions of the two sarcoglanidines herein analyzed yielded a novel topology that remained consistent between the two analytical methods (BI and ML) with considerable statistical support. Nevertheless, the topologies advanced by previous morphological studies of inter-subfamilial relationships could not be rejected by the present molecular analysis according to the topology test (Table 3).

The monophyletic assemblage of the subfamilies Copionodontinae and Trichogeninae, identified as Clade B in Datovo and Bockmann (2010), was originally suggested by de Pinna (1998) and corroborated by Bichuette et al. (2008). These subfamilies share the derived presence of an anterior process at the anterolateral corner of hypobranchial 1, the endopterygoid ankylosed to the ventral surface of the autopalatine, and an enlarged subtemporal fossa (de Pinna, 1998). Datovo and Bockmann (2010) additionally found a myological synapomorphy for the clade, consisting in the presence of the adductor hyomandibulae muscle, a morphological character that is functionally linked to the hollow ventral surface of the pterotic (subtemporal fossa). This clade is the sister group to all other trichomycterids and exhibits the plesiomorphic condition for several characters uniquely derived in the remaining 


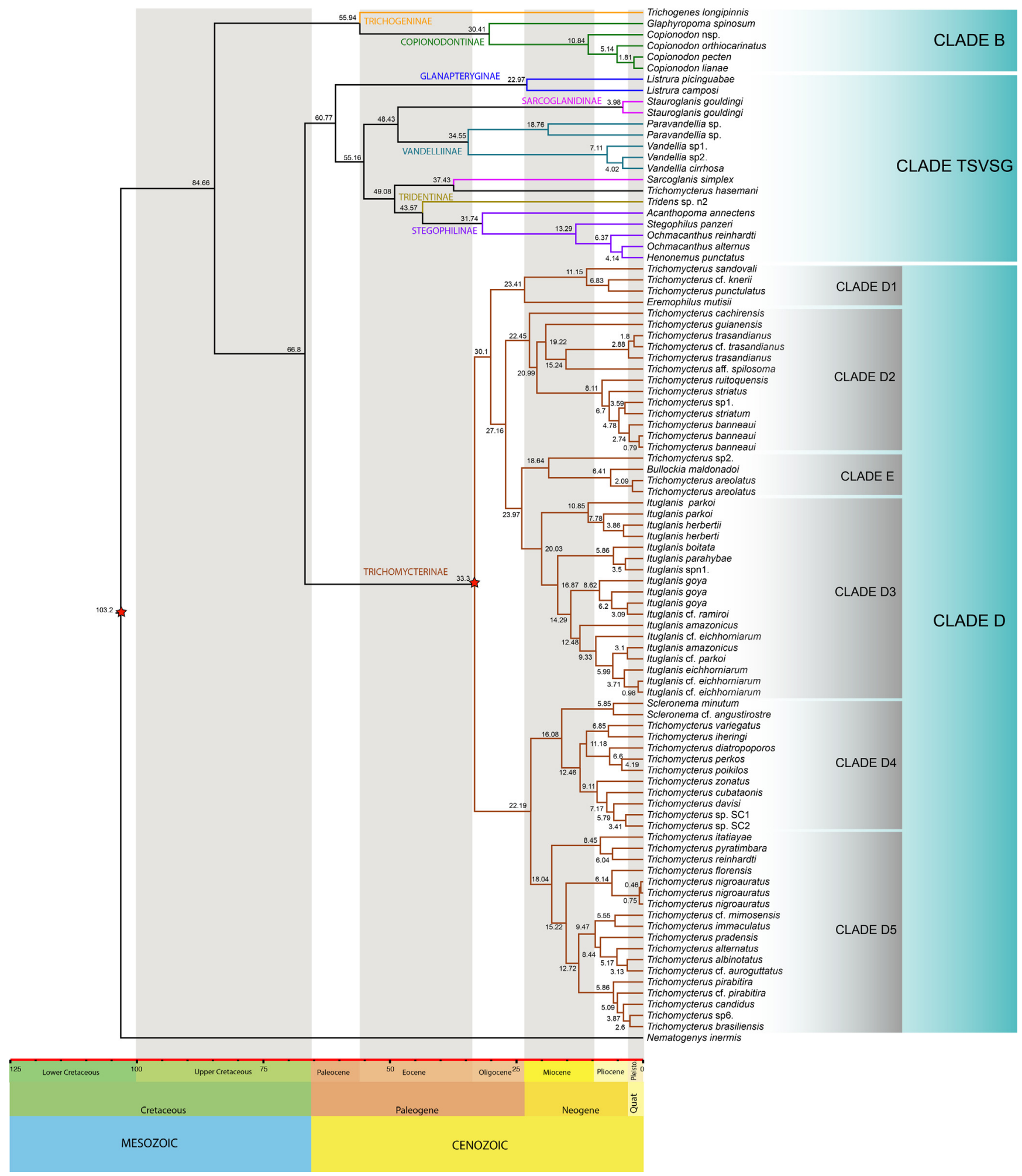

Fig. 3. Maximum clade credibility (MCC) tree of Trichomycteridae obtained from BEAST analysis.

trichomycterids (de Pinna, 1998; Datovo and Bockmann, 2010). Therefore, the monophyly of this clade and its phylogenetic placement at the base of the Trichomycteridae is supported by both morphology and molecules hypotheses.

The group comprising all subfamilies of the Trichomycteridae with the exception of Copionodontinae and Trichogeninae (identified as Clade C in Datovo and Bockmann, 2010), was also recovered in the present molecular analysis, despite some disagreement in the composition. Results from both inferences herein obtained, divided Clade C into two subclades, the TSVSG clade (Costa and Bockmann, 1993) and the Trichomycterinae as redefined by Datovo and Bockmann (2010). Our hypothesis of a monophyletic group including all trichomycterines and members of the TSVSG clade corroborates previous morphological studies (de Pinna, 
1992, 1998; Bockmann et al., 2004; Datovo and Bockmann, 2010) based on a wealth of anatomical support: anterior cranial fontanel partially or completely closed; sphenotic, prootic, and pterosphenoid fused; Weberian capsule with a small opening, much smaller than its lateral profile; interhyal absent; five or fewer pelvic-fin rays; dorsal caudal-fin plate with six or fewer rays; dorsal caudal-fin lobe with five or fewer branched rays; ventral caudalfin plate with eight or fewer rays; ventral caudal-fin lobe with six or fewer branched rays; incomplete infraorbital branch of the laterosensory canal system; presence of a protractor operculi muscle; and levator operculi muscle with fibers posterodorsally oriented towards its origin.

Despite the low support values $(P=0.58, \mathrm{BS}=57)$ the monophyly of the TSVSG clade is corroborated by previous studies (Costa and Bockmann, 1994; Fernández and Schaefer, 2009) and it is supported by four shared derived morphological characters: absence of a posterior process of the parasphenoid; extreme reduction or absence of the metapterygoid, interopercular patch of odontodes reduced, being nearly as long as deep; and primary section of the dilatator operculi passing dorsolateral to the levator arcus palatini (Costa and Bockmann, 1993; de Pinna, 1998; Datovo and Bockmann, 2010). A major source of incongruence between our hypothesis and previous phylogenetic arrangements lay in the internal relationships of the TSVSG clade. The main departures in the genetic analysis are the non-monophyly of the Sarcoglanidinae, with Sarcoglanis being more closely related to "Trichomycterus" hasemani, and Stauroglanis more closely related to Vandelliinae (Paravandellia and Vandellia). This internal arrangement of the TSVSG clade (Fig. 2) is highly supported in BI but not in ML analysis. Most morphological studies (Baskin, 1973; Costa and Bockmann, 1994; de Pinna, 1998; Datovo and Bockmann, 2010) and previous molecular analyses (Fernández and Schaefer, 2009) supported a sister group relationship between the Sarcoglanidinae and Glanapteryginae, with the following shared derived morphological features: reduced vomer; reduced number of premaxillary teeth; quadrate with a posteriorly-directed anterodorsal process; anterior portion of the hyomandibula modified into a long process; seven or fewer anal-fin rays; and insertion of the stegalis (sensu Datovo and Vari, 2013, 2014; =A3) section of the adductor mandibulae onto the buccopalatal membrane.

The Sarcoglanidinae was established by Myers and Weitzman (1966) to include Sarcoglanis simplex and Malacoglanis gelatinosus. New genera were subsequently described and added: Stauroglanis (de Pinna, 1989a), Stenolicmus (de Pinna and Starnes, 1990), Microcambeva (Costa and Bockmann, 1994), and Ammoglanis (Costa, 1994). The monophyletic status of this subfamily has been successively reexamined during the last two decades (Datovo and Bockmann, 2010) and only the inclusion of Ammoglanis pulex has been questioned (de Pinna and Winemiller, 2000). The monophyly of the Sarcoglanidinae is supported by a large set of osteological (de Pinna, 1989a; Costa, 1994) and myological (Datovo and Bockmann, 2010) synapomorphies. The sister group relationship between Sarcoglanis simplex and "Trichomycterus" hasemani is unexpected and novel, since this is the first molecular analysis to include both taxa. Morphological studies have placed " $T$." hasemani sister to a clade formed by the Tridentinae, Stegophilinae, and Vandelliinae ( $=$ Vandelliinae-group), either analyzing it alone (DoNascimiento, 2015) or as part of the "T." hasemani group, which also includes "T." johnsoni, and "T." anhinga, and "T". wapixana (Dutra et al., 2012; see next section). In our analysis, long-branch attraction and likely incomplete lineage sorting may be responsible for the non-monophyly of Sarcoglanidinae, as well as the lack of support for the clade Sarcoglanidinae + Glanapteryginae. Our sampling of both subfamilies was incomplete (two of six sarcoglanidine genera and only one of four glanapterygine genera). The two sarcoglanidine genera in our analysis (Sarcoglanis and Stauroglanis) occupy rather distal positions in the subfamilial phylogeny inferred from morphology (summarized in Costa, 1994) and Sarcoglanis simplex has a remarkable highly specialized morphology.

Previous morphological (Baskin, 1973; de Pinna, 1998; Datovo and Bockmann, 2010) and molecular (Fernández and Schaefer, 2009) analyses hypothesized the monophyly of the Vandelliinaegroup, a clade formed by the Tridentinae, Stegophilinae, and Vandelliinae. Such an arrangement is not recovered in the present study, with the Vandelliinae appearing more closely related to the Glanapteryginae and the sarcoglanidine Stauroglanis than to tridentines and stegophilines. Another point of disagreement corresponds to the relationship between the semiparasitic subfamilies Stegophilinae and Vandelliinae. Most studies (Baskin, 1973; de Pinna, 1998; Fernández and Schaefer, 2009; DoNascimiento, 2015) have supported a sister relationship between those two subfamilies. Datovo and Bockmann (2010) provided myological evidence favoring an alternative hypothesis in which Tridentinae and Stegophilinae are sister taxa. These authors, however, confirm the validity of anatomical characters supporting the traditional hypothesis and concludes that the relationships between the three subfamilies could not be decisively determined based on the morphological evidence available. Our results reinforce the myological evidence presented by Datovo and Bockmann (2010) and is the first study to provide molecular support for the hypothesis of a tridentine-stegophiline group.

\subsection{The subfamily Trichomycterinae}

Baskin (1973) was the first to suggest the non-monophyly of the Trichomycterinae. de Pinna (1989a) corroborated his hypothesis based on the lack of synapomorphies for the subfamily and the possible closer relationship of some species with other subfamilies: Scleronema, Trichomycterus boylei, and T. santaeritae would be more closely related to the Sarcoglanidinae and " $T$ ". hasemani and " $T$ ". johnsoni more closely related to the Tridentinae. Whereas the former hypothesis has been rejected (Arratia, 1990; Costa and Bockmann, 1993, 1994; de Pinna, 1998; Datovo and Bockmann, 2010), the latter was partially corroborated by subsequent morphological studies (Datovo and Bockmann, 2010; Dutra et al., 2012; DoNascimiento, 2015). The present analysis is the first molecular evidence corroborating the exclusion of " $T$." hasemani from the Trichomycterinae, although in our topology this species is more closely related to Sarcoglanis (Sarcoglanidinae) than to members of the Vandelliinae-group. The so-called "T." hasemani group ("T". anhanga, " $T$ ". hasemani, and "T". johnsoni, and " $T$ ". wapixana; Dutra et al., 2012) remains provisionally classified as Trichomycterus while its formal description as a new trichomycterid genus and subfamily is still underway (by W. Wosiacki and M. C. C. de Pinna; pers. comm.).

Arratia (1990) proposed four synapomorphies in supporting a monophyletic Trichomycterinae, none of which were present in "Trichomycterus" hasemani (de Pinna, 1998). Costa and Bockmann (1993) and de Pinna (1998), on the other hand, advanced that Ituglanis and Scleronema were more closely related to the TSVSG clade than to remaining trichomycterines, a result not corroborated by the present analysis. More recently, Datovo and Bockmann (2010) and Datovo et al. (2016) revised the characters proposed to support these two alternative hypotheses and concluded that none of them were valid. The authors, however, concluded that the Trichomycterinae exclusive of the "T." hasemani group could form a monophyletic group on the basis of the shared presence of a posterior portion of the levator internus IV originated from the dorsal face of the posttemporo-supracleithrum. Thus, the present analysis based on representatives of five trichomycterine genera (Bullockia, Eremophilus, Ituglanis, Scleronema, and Trichomycterus; missing Hatcheria, Rhizosomichthys, and Sil- 
vinichthys), supports the monophyly of the Trichomycterinae (clade D) as circumscribed by Datovo and Bockmann (2010).

In our topology, the Trichomycterinae is divided into two large clades: one including all species from Atlantic coastal drainages and Upper Paraná (Scleronema and part of Trichomycterus; clade D4 + D5) and another primarily including Amazonian and transAndean taxa (Bullockia, Eremophilus, Ituglanis, and part of Trichomycterus; clade D1 + D2 +E +D3). Such a scheme contradicts previous hypotheses in which Scleronema and Ituglanis are in some way closely related (Costa and Bockmann, 1993; de Pinna, 1998). The monophyletic status of genus Ituglanis (clade D3) is highly supported, in agreement with the morphological studies (Costa and Bockmann, 1993; Datovo and de Pinna, 2014; Datovo et al., 2016; Wosiacki et al., 2012). De Pinna and Keith (2003) tentatively proposed the existence of two monophyletic groups within the genus, one including species from the Amazon and Guiana shield and another primarily formed primarily by species from the La Plata system and Atlantic coastal drainages. This hypothesis has been challenged in light of additional anatomical evidence and newly discovered taxa (Datovo and Landim, 2005; Datovo, 2014; Datovo and de Pinna, 2014). Our analysis refuted de Pinna and Keith's (2003) proposal, with the clustering of species from the Amazon and Paraguay in two occasions: in one clade, including $I$. herberti and I. parkoi, and a second lineage that includes I. amazonicus, I. eichhorniarum. It is worth mentioning, however, that identity and limits of the three latter species are poorly understood and some terminals are only tentatively assigned to these taxa ( $I$. amazonicus, I. cf. eichhorniarum, and I. cf. parkoi). Interestingly, all analyzed species from the Atlantic coastal drainages (I. boitata, I. parahybae, and Ituglanis. sp. n. 1) are herein highly supported as forming a monophyletic lineage. A fourth major clade of Ituglanis grouped the epigean I. goya and the hypogean I. cf. ramiroi, both from the lower Tocantins basin.

The sister group of Ituglanis is Clade E composed of Bullockia, Trichomycterus areolatus and an undescribed Trichomycterus from Sepotuba River, upper Paraguay River basin. A previous study of DoNascimiento (2015) clustered Bullockia, Hatcheria, and Trichomycterus areolatus. Datovo and Bockmann (2010) included to this clade another Chilean species, T. chiltoni and other two from southern Brazil to this clade, Trichomycterus immaculatus and $T$. zonatus, but our molecular results nested those species in different clades, D5 and D4 respectively.

Our molecular results corroborated the non-monophyletic status of Trichomycterus as previously hypothesized by several studies (Baskin, 1973; de Pinna, 1989a,b, 1998; Arratia, 1998; Datovo and Bockmann, 2010). Identity of the type species of Trichomycterus, $T$. nigricans, is surrounded by uncertainties and conflicting information (A. Datovo, in prep.), but its type locality is certainly an Atlantic coastal drainage in Brazil. In our analysis, species of Trichomycterus from this area are restricted to sister clades D4 and D5. Clade D4 also includes two species of Scleronema, S. minutum and Scleronema cf. angustirostre.

In spite of the present study to be the most comprehensive phylogenetic analysis of the Trichomycterinae published to date, including 70 representative terminals, taxonomic changes at this moment are premature considering the constant increase in the description of new species assigned to the genus Trichomycterus, as well as, the incomplete genera representation of some subfamilies. Nevertheless, our results constitute an important evidence for the necessary nomenclatural changes within Trichomycterus, which should be ideally associated with the geographical distribution of the clades herein identified. Based on our results, clades containing species of the Trichomycterus from trans-Andean basins (D1, D2, E) are more closely related to Ituglanis (Clade D3) than to clades containing species of Trichomycterus from Atlantic coastal drainages, which probably are more related with the type species of this genus. Finally, we suggest that revisionary studies of key taxa at the generic level, an increase in the molecular information and its integration with morphological data are crucial to confidently to perform accurate nomenclatural decisions in the subfamily.

\subsection{Timing of diversification}

Molecular-clock methods provide neontological tools for estimating the temporal origins of clades (Hipsley and Müller, 2014) and linking cladogenesis to major events in geohistory. For example, Lundberg et al. (2007) used a fossil-calibrated, relaxed-clock molecular analysis to estimate the divergence of the Neotropical freshwater catfish, Lacantunia enigmatica, from its closest relatives which are endemic to Africa. Based on the estimated age of Lacantunia (83-86.5 Mya), its occurrence in the New World is more likely attributable to dispersal via Holarctic land bridges from the Late Cretaceous to Late Miocene than to older vicariant events associated with the breakup of Pangea and subsequently Gondwana. Employing similar methods, Sullivan et al. (2013) estimated that the Neotropical superfamily Pimelodoidea (long-whiskered catfishes) originated between 110 and $95 \mathrm{Mya}$, and that its five major lineages (family-level clades) split off soon afterward during a period of explosive diversification. Based on the fossil records of pimelodoids and other Neotropical fishes, the freshwater fauna of South America appears to have been essentially modern by the mid-Miocene (Lundberg et al., 1998, 2010; Sullivan et al., 2013).

Trichomycteridae is one of six family-level groups in Loricariodei, a suborder that is endemic to the Neotropic and sister to all other catfishes (Sullivan et al., 2006). Our estimate of the origin of Trichomycteridae (103.2 Mya) is approximated the time of the rifting caused the connection between the Central and South Atlantic (ca. 100 Mya; Torsvik et al., 2008) which severed the last continental connection between Africa and South America. The oldest split within Trichomycteridae is estimated at 84.66 Mya and established the clade Copionodontinae + Trichogeninae. Extant members of this clade are restricted to a few, relatively small Atlantic tributaries in eastern and southeastern Brazil. Ribeiro (2006) used this split to exemplify the initial (Cretaceous) phase of diversification contributing to an ancient fish fauna endemic to Brazilian coastal rivers (his "Pattern A"). He linked Pattern A cladogenesis to the original Atlantic coastal drainages that were probably structurally oriented by megadomes, large faults and grabens. The second major split within the Trichomycteridae appears to have established two large clades, TSVSG and Trichomycterinae, just before the K-T Boundary (ca. 65.5 Mya).

The TSVSG and Trichomycterinae clades provide more examples of cladogenesis involving Atlantic coastal drainages. The first group to diverge in the TSVSG clade is Listrura (60.8 Mya), a genus restricted to coastal streams of southern and southeastern Brazil. The remaining members of the TSVSG clade are restricted to larger cis and trans-Andean basins that were variously interconnected throughout the Cenozoic. Within the Trichomycterinae, there are two major clades containing Atlantic coastal taxa, D3 and D4 + D5. By our estimates, Clade D4 + 5 split from the remaining trichomycterines 33.3 Mya (Lower Oligocene). This clade is composed exclusively of taxa from Atlantic coastal drainages and tributaries to the Paraná-Paraguay basin. Clade D3 is younger, established 24 Mya (Upper Oligocene), and includes species of the genus Ituglanis from both Atlantic coastal drainages and the major cis-Andean drainages (Amazonas, Paraná-Paraguay system, Tocantins, and Amazonas River basin). Our results therefore suggested that separate geological events are responsible for the modern-day fauna of Atlantic coastal trichomycterines.

The distribution and diversification of fishes in Atlantic coastal tributaries are commonly attributed to sea level changes during the Late Pleistocene (Weitzman et al., 1988; Thomaz et al., 2015). 
Ribeiro (2006) argued that changes in sea level fail to explain the occurrence of closely related taxa in both coastal drainages and upland rivers draining the Brazilian Shield inland towards much larger basins such as the Paraná-Paraguay system. Alternatively, he hypothesized megadome uplifts, rifting, vertical movements between rifted blocks and the erosive retreat of the eastern continental margin of South America to be the main geological forces controlling the biogeography of Atlantic coastal fishes. Those forces gave rise to taphrogenic (rift related) basins along the Brazilian coast that repeatedly captured adjacent upland drainages, providing a one-way conduit for introducing upland taxa to Atlantic coastal basins. Ribeiro (2006) asserted that only significant tectonic deformations could account for dispersal in the opposite direction whereby fishes common to coastal basins are introduced to upland rivers draining inland. Our results point to the Miocene as an active period for such geological events in concert with the diversification of trichomycterins in clades D3 and D4 + 5.

Of equal interest are dates of origin estimated for trichomycterine clades D1, D2 and E. Together with clade D3 (Ituglanis), those groups are one of the first two clades to diverge within Trichomycterinae 33.3 Mya. Clades D1, D2 and E are dominated by taxa from trans-Andean drainages (e.g., Magdalena, Pacific coastal drainages). According to our analysis, clade D1 was the first to split off 30.1 Mya, followed by D2 at 27.2 Mya. The last split between clade E (Bullockia and two species of Trichomycterus) and clade D3 (Ituglanis) is estimated at 24 Mya. Those major cladogenetic events pointed to the Oligocene as an active time for the impact of the Andean uplift on local drainage patterns. Of special interest is the placement of Trichomycterus cf guianensis within clade D2. Trichomycterus of guianensis is a species complex endemic to upland left-bank tributaries of the Essequibo River which drain a portion of the Guiana Shield into the Atlantic Ocean. Our results nested T.cf. guianensis within clade D2 as sister to a group composed of Trichomycterus from the Magdalena and a Pacific versant in Ecuador. As one would expected, the timing of that split, 19.2 Mya (Lower Miocene), predates the estimated isolation of the Magdalena River via the uplift of the Northern Andes 711 Mya (plate 15 in Hoorn and Wesseling, 2010).

Overall, the tempo of diversification within the Trichomycteridae is consistent with that described by molecular-clock analyses of other Neotropical catfishes (Lundberg et al., 2007; Sullivan et al., 2013). Likewise, trichomycterid diversity appears to have been essentially modern by the mid-Miocene and largely shaped by Paleogene events in the geohistory of South America.

\section{Acknowledgments}

The authors are grateful to Dr. Mario C. C. de Pinna for many species identifications, Dr Mahmoud Mehanna for access to samples of Trichomycterus and Mr. Jorge Enrique Garcia-Melo for help with artwork. Research was funded by the Brazilian agency FAPESP grant 2014/06853-8 and 2015/13382-4 to LEO, grant 2014/050515 and 2015/00691-9 to FFR and MCT/CNPq Universal grant 441347/2014-2 to coord. FFR. Grant FAPESP 2010/17009-2, FAPESP 2014/26508-3, CNPQ 306054/2006-0 to CO. Contributions by MHS were supported by iXingu Project (NSF DEB-1257813).

\section{Appendix A. Supplementary material}

Supplementary data associated with this article can be found, in the online version, at http://dx.doi.org/10.1016/j.ympev.2017.07. 007.

\section{References}

Adriaens, D., Baskin, J.N., Coppens, H., 2010. Evolutionary morphology of trichomycterid catfishes: about hanging on and digging. In: Nelson, J.S. Schultze, H.P., Wilson, M.V.H. (Eds.), Origin and Phylogenetic Interrelationships of Teleosts. München, Verlag Dr, Friedrich Pfeil, pp. 337-362.

Arratia, G., Menu-Marque, S., 1984. New catfishes of the genus Trichomycterus from the high Andes of South America (Pisces, Siluriformes) with remarks on distribution and ecology. Zoologische Jahrbücher. Abteilung für Systematik, Ökologie und Geographie der Tiere 111 (4), 493-520.

Arratia, G., 1990. The South American Trichomycterinae (Teleostei: Siluriformes), a problematic group. In: Peters, G., Hutterer, R. (Eds.), Vertebrates in the Tropics: Proceedings of the International Symposium on Vertebrate Biogeography and Systematics in the Tropics, Bonn, June 5-8, 1989. Alexander Koenig Zoological Research Institute and Zoological Museum, Bonn, Germany, pp. 395-403.

Arratia, G., 1998. Silvinichthys, a new genus of trichomycterid catfishes from the Argentinian Andes, with redescription of Trichomycterus nigricans. Ichthyol. Explor. Freshw. 9, 347-370.

Arratia, G., Huaquín, L., 1995. Morphology of the lateral line system and of the skin of diplomystid and certain primitive catfishes and systematic and ecological considerations. Bonn Zool Monogr. 36, 1-110.

Barbosa, M.A., Costa, W.J.E.M., 2010. Seven new species of the catfish genus Trichomycterus (Teleostei: Siluriformes: Trichomycteridae) from southeastern Brazil and redescription of T. brasiliensis. Ichthyol. Explor. Freshw. 21 (2), 97122.

Baskin, J.N., 1973. Structure and Relationships of the Trichomycteridae Unpubl. Ph. D. diss. City University of New York, New York.

Betancur-R, R., Ortí, G., Pyron, R.A., 2015. Fossil-based comparative analyses reveal ancient marine ancestry erased by extinction in ray-finned fishes. Ecol. Lett. 18 $441-450$.

Bichuette, M.E., de Pinna, M.C.C., Trajano, E., 2008. A new species of Glaphyropoma: the first subterranean copionodontine catfish and the first occurrence of opercular odontodes in the subfamily (Siluriformes: Trichomycteridae). Neotrop. Ichthyol. 6 (3), 301-306.

Bockmann, F.A., Casatti, L., de Pinna, M.C.C., 2004. A new species of trichomycteric catfish from the Rio Paranapanema, southeastern Brazil (Teleostei: Siluriformes), with comments on the phylogeny of the family. Ichthyol. Explor. Freshw. 15, 225-242.

Bogan, S., Agnolin, F., 2009. Primer registro fósil de la familia Trichomycteridae (Teleostei: Siluriformes; Plioceno) en la Formación Monte Hermoso, Argentina. Rev. Mus. Argent. Cienc. Nat. 11 (2), 193-198.

Costa, W.J.E.M., Bockmann, F.A., 1993. Un nouveau genre Néotropical de la famille des Trichomycteridae (Siluriformes: Loricarioidei). Revue Fr. Aquariol. 20 (2), 43-46.

Costa, W.J.E.M., 1994. A new genus and species of Sarcoglanidinae (Siluriformes: Trichomycteridae) from the Araguaia basin, central Brazil, with notes on subfamilial phylogeny. Ichthyol. Explor. Freshw. 5, 207-216.

Costa, W.J.E.M., Bockmann, F.A., 1994. A new genus and species of Sarcoglanidinae (Siluriformes: Trichomycteridae) from southeastern Brazil, with a reexamination of subfamilial phylogeny. J. Nat. Hist. 28, 715-730.

Datovo, A., 2014. A new species of Ituglanis from the Rio Xingu basin, Brazil, and the evolution of pelvic fin loss in trichomycterid catfishes (Teleostei: Siluriformes: Trichomycteridae). Zootaxa 3790, 466-476.

Datovo, A., Aquino, P.P.U., Langeani, F., 2016. A new species of Ituglanis (Siluriformes: Trichomycteridae) from the Tocantins and Paranaíba river basins, central Brazil, with remarks on the systematics of the genus. Zootaxa. 4171 (3), 439-458.

Datovo, A., de Pinna, M.C.C., 2014. A new species of Ituglanis representing the southernmost record of the genus, with comments on phylogenetic relationships (Teleostei: Siluriformes: Trichomycteridae). J. Fish. Biol. 84, 314-327.

Datovo, A., Landim, M.I., 2005. Ituglanis macunaima, a new catfish from the rio Araguaia basin, Brazil (Siluriformes: Trichomycteridae). Neotrop. Ichthyol. 3, $455-464$.

Datovo, A., Bockmann, F.A., 2010. Dorsolateral head muscles of the catfish families Nematogenyidae and Trichomycteridae (Siluriformes: Loricarioidei): comparative anatomy and phylogenetic analysis. Neotrop. Ichthyol. 8, 193-246.

Datovo, A., Vari, R.P., 2013. The jaw adductor muscle complex in teleostean fishes: evolution, homologies and revised nomenclature (Osteichthyes: Actinopterygii). PLoS One 8, e60846.

Datovo, A., Vari, R.P., 2014. The adductor mandibulae muscle complex in lower teleostean fishes (Osteichthyes: Actinopterygii): comparative anatomy, synonymy, and phylogenetic implications. Zool. J. Linnean. Soc. 171, 554-622.

DoNascimiento, C., 2015. Morphological evidence for the monophyly of the subfamily of parasitic catfishes Stegophilinae (Siluriformes, Trichomycteridae) and phylogenetic diagnoses of its genera. Copeia 103 (4), 933-960.

Drummond, A.J., Suchard, M.A., Xie, D., Rambaut, A., 2012. Bayesian phylogenetics with BEAUti and the BEAST 1.7. Mol. Biol. Evol. 29, 1969-1973.

Dutra, G.M., Wosiacki, W.B., de Pinna, M.C.C., 2012. Trichomycterus anhanga, a new species of miniature catfish related to T. hasemani and T. johnsoni (Siluriformes: Trichomycteridae) from the Amazon basin, Brazil. Neotrop. Ichthyol. 10 (2), 225-231.

Edgar, R.C., 2004. MUSCLE: multiple sequence alignment with high accuracy and high throughput. Nucleic Acids Res. 32 (5), 1792-1797. 
Eigenmann, C.H., 1918. The Pygidiidae, a family of South American catfishes. Mem. Carnegie. Mus. 7 (5), 259-398.

Eigenmann, C.H., 1927. The freshwater fishes of Chile. Mem. Nat. Acad. Sci., 1-63

Eschmeyer, W.N. Fricke, R., van der Laan, R., 2017. Catalog of fishes: genera, species, references. (http://researcharchive.calacademy.org/research/ ichthyology/catalog/fishcatmain.asp). (Electronic version accessed 24 January 2017).

Fernández, L., Schaefer, S.A., 2005. New Trichomycterus (Siluriformes: Trichomycteridae) from an offshore island of Colombia. Copeia 2005, 68. 68-67.

Fernández, L., Schaefer, S.A., 2009. Relationships among the Neotropical Candirus (Trichomycteridae, Siluriformes) and the evolution of parasitism based on analysis of mitochondrial and nuclear gene sequences. Mol. Phylogenet. Evol. 52 (2), 416-423.

García-Melo, L.J., Villa-Navarro, F.A., DoNascimiento, C., 2016. A new species of Trichomycterus (Siluriformes: Trichomycteridae) from the upper río Magdalena basin, Colombia. Zootaxa 4117, 226-240.

Huelsenbeck, J.P., Ronquist, F., 2001. MrBayes: Bayesian inference of phylogenetic trees. Bioinformatics 17, 754-755.

Hipsley, C.A., Müller, J., 2014. Beyond fossil calibrations: realities of molecular clock practices in evolutionary biology. Front. Genet. 5, 138. http://dx.doi.org/ 10.3389/fgene.2014.00138.

Hoorn, C., Wesseling, F.P., 2010. Amazonia-Landscape and Species Evolution: A Look Into the Past. Wiley-Blackwell.

Irwin, D.M., Kocher, T.D., Wilson, A.C., 1991. Evolution of the cytochrome b gene of mammals. J. Mol. Evol. 32 (2), 128-144.

Kocher, T.D., Thomas, W.K., Meyer, A., Edwards, S.V., Pääbo, S., Villablanca, F.X Wilson, A.C., 1989. Dynamics of mitochondrial DNA evolution in animals: amplification and sequencing with conserved primers. Proc. Natl. Acad. Sci. U. S. A. 86 (16), :6196-200.

Lanfear, R., Calcott, B., Ho, S.Y.W., Guindon, S., 2012. PartitionFinder: combined selection of partitioning schemes and substitution models for phylogenetic analyses. Mol. Biol. Evol. 29, 1695-1701.

Li, C., Ortí, G., Zhang, G., Lu, G., 2007. A practical approach to phylogenomics: the phylogeny of ray-finned fish (Actinopterygii) as a case study. BMC Evol. Biol. 7, 44.

Lovejoy, N.R., Collette, B.B., 2001. Phylogenetic relationships of new world needlefishes (Teleostei: Belonidae) and the biogeography pf transitions between marine and freshwater habitats. Copeia 2, 324-338.

Lundberg, J.G., Sullivan, J.P., Rodiles-Hernández, R., Hendrickson, D.A., 2007. Discovery of African roots for the Mesoamerican Chiapas catfish, Lacantunia enigmatica, requires and ancient intercontinental passage. Proc. Acad. Nat. Sci. Philadelphia 156, 39-53.

Lundberg, J.G., Marshall, L.G., Guerrero, J., Horton, B., Malabarba, M.C.S.L., Wesselingh, F., 1998. The stage for neotropical fish diversification: a history of tropical South American rivers. In: Malabarba, L.R., Reis, R.E., Vari, R.P., Lucena, Z.M., Lucena, C.A.S. (Eds.), Phylogeny and Classification of Neotropical Fishes. EDIPUCRS, Porto Alegre, p. 603.

Lundberg, J.G., Sabaj Pérez, M.H., Dahdul, W.M., Aguilera, O.A., 2010. The Amazonian Neogene fish fauna. In: Hoorn, C., Wesselingh, F.P. (Eds.), Amazonian, Landscape and Species Evolution: A Look into the Past. Wiley-Blackwell Publishing Ltd. Oxford, UK, pp. 281-301.

Maddison, W.P., Maddison, D.R., 2011. Mesquite: a modular system for evolutionary analysis. Version 2, 75 http://mesquiteproject.org.

Miller, M.A., Pfeiffer, W., Schwarts, T., 2010. Creating the CIPRES science gateway for inference of large phylogenetic trees. In: Proceeding of the Gateway Computing Environments Workshop (GCE), 14 Nov. 2010, New Orleans, LA, pp. 1-8.

Myers, G.S., Weitzman, S.H., 1966. Two remarkable new trichomycterid catfishes from the Amazon basin in Brazil and Colombia. J. Zool. 149 (3), 277-287.

Oliveira, C., Avelino, G.S., Abe, K.T., Mariguela, T.C., Benine, R.C., Ortí, G., Vari, R.P., Castro, R.M.C., 2011. Phylogenetic relationships within the speciose family Characidae (Teleostei: Ostariophysi: Characiformes) based on multilocus analysis and extensive ingroup sampling. BMC Evolut. Biol. 11, 275.

Palumbi, S.R., 1996. Nucleic acids II: the polymerase chain reaction. Mol. Syst. 2 (1), 205-247.

de Pinna, M.C.C., 1989a. A new sarcoglanidine catfish, phylogeny of its subfamily, and an appraisal of the phyletic status of the Trichomycterinae (Teleostei, Trichomycteridae). Am. Mus. Novit. 2950, 1-39.

de Pinna, M.C.C., 1989b. Redescription of Glanapteryx anguilla, with notes on the phylogeny of Glanapteryginae (Siluriformes, Trichomycteridae). Proc. Acad. Nat. Sci. Philadelphia 141, 361-374.

de Pinna, M.C.C., Britski, H.A., 1991. Megalocentor, a new genus of parasitic catfish from the Amazon basin: the sister group of Apomatoceros (Trichomycteridae: Stegophilinae). Ichthyol. Explor. Freshw. 2, 113-128.

de Pinna, M.C.C., 1992. A new subfamily of Trichomycteridae (Teleostei, Siluriformes), lower loricarioidea relationships and a discussion on the impac of additional taxa for phylogenetic analysis. Zool. J. Linn. Soc. 106, 175-229. de Pinna, M.C.C., 1998. Phylogenetic relationships of Neotropical Siluriformes: historical overview and synthesis of hypotheses. In: Malabarba, L.R., Reis, R.E., Vari, R.P., Lucena, Z.M.S., Lucena, C.A.S. (Eds.), Phylogeny and classification of Neotropical fishes EDIPUCRS, Porto Alegre, pp. 279-330.

de Pinna, M.C.C., Starnes, W.C., 1990. A new genus of Sarcoglanidinae from the Rio Mamore, Amazon basin, with comments on subfamilial phylogeny (Teleostei, Trichomycteridae). J. Zool. 149, 75-78.

de Pinna, M.C.C., Winemiller, K.O., 2000. A new species of Ammoglanis (Siluriformes: Trichomycteridae) from Venezuela. Ichthyol. Explor. Freshw. 11 (3), 255-264.

de Pinna, M.C.C., Wosiacki, W.B., 2003. Family Trichomycteridae (pencil or parasitic catfishes). In: Reis, R.E., Kullander, S.O., Ferraris, C.J., Jr. (Eds.), Checklist of the Freshwater Fishes of South and Central America. EDIPUCRS, Porto Alegre, pp. 270-290.

de Pinna, M.C.C., Helmer, J.L., Britski, H.A., Rodrigues-Nunes, L., 2010. A new species of Trichogenes from the rio Itapemirim drainage, southeastern Brazil, with comments on the monophyly of the genus (Siluriformes: Trichomycteridae). Neotrop. Ichthyol. 8, 707-717.

Rambaut, A., Drummond, A.J., 2007. Tracerv1.5. http://beast.bio.ed.ac.uk/Tracer. (Accessed 13.02.13).

Rambaut, A., Drummond, A.J., 2007. TreeAnnotator v1.7.5. http://beast.bio.ed.ac.uk/ TreeAnnotator. (Accessed 13.02.13).

Ribeiro, A., 2006. Tectonic history and the biogeography of the freshwater fishes from the coastal drainages of eastern Brazil: an example of faunal evolution. Neotrop. Ichthyol. 4 (2), 225-246.

Rizzato, P.P., Costa Jr., E.P.D., Trajano, E., Bichuette, M.E., 2011. Trichomycterus dali: a new highly troglomorphic catfish (Siluriformes: Trichomycteridae) from Serra da Bodoquena, Mato Grosso do Sul State, Central Brazil. Neotrop. Ichthyol. 9 (3), 477-497.

Ronquist, F., Huelsenbeck, J.P., 2003. MrBayes 3: Bayesian phylogenetic inference under mixed models. Bioinformatics 19, 1572-1574.

Shimodaira, H., Hasegawa, M., 1999. Multiple comparisons of log-likelihoods with applications to phylogenetic inference. Mol. Biol. Evol. 16, 1114-1116.

Stamatakis, A., 2006. RAxML-VI-HPC: maximum likelihood- based phylogenetic analyses with thousands of taxa and mixed models. Bioinformatics 22, 26882690.

Sullivan, J.P., Lundberg, J.G., Hardman, M., 2006. A phylogenetic analysis of the major groups of catfishes (Teleostei: Siluriformes) using rag1 and rag2 nuclear gene sequences. Mol. Phylogenet. Evol. 40, 636-662.

Sullivan, J.P., Muriel-Cunha, J., Lundberg, J.G., 2013. Phylogenetic relationships and molecular dating of the major groups of catfishes of the Neotropical superfamily Pimelodoidea (Teleostei, Siluriformes). Proc. Acad. Nat. Sci. Philadelphia 162 (1), 89-110.

Thomaz, A.T., Arcila, D., Ortí, G., Malabarba, L.R., 2015. Molecular phylogeny of the subfamily Stevardiinae Gill, 1858 (Characiformes: Characidae): classification and the evolution of reproductive traits. BMC Evol. Biol. 15, 146.

Tomassini, R.L., Montalvo, C.I., Deschamps, C.M., Manera, T., 2013. Biostratigraphy and biochronology of the Monte Hermoso Formation (early Pliocene) at its type locality, Buenos Aires Province, Argentina. J. South Am. Earth Sci. 48, 31-42.

Torsvik, T.H., Müller, R.D., Van der Voo, R., Steinberger, B., Gaina, C., 2008. Global plate motion frames: Toward a unified model. Rev. Geophys. 46, RG3004. http:// dx.doi.org/10.129/2007/RG000227.

Ward, R.D., Zemlak, T.S., Innes, B.H., Last, P.R., Hebert, P.D., 2005. DNA barcoding Australia's fish species. Philos. Trans. R. Soc. Lond. B Biol. Sci. 360 (1462), $1847-$ 1857.

Weitzman, S.H., Menezes, N.A., Weitzman, M.J., 1988. Phylogenetic biogeography of the glandulocaudini (Teleostei: Characiformes, Characidae) with comments on the distribution of other freshwater fishes in eastern and southeastern Brazil. In: Vanzolini, P.E., Heyer, W.R. (Eds.), Proceedings of a Workshop on Neotropical Distribution Patterns. Academia Brasileira de Ciências, Rio de Janeiro, pp. 379427. 488.

Wosiacki, W.B., Dutra, G.M., Mendoça, M.B., 2012. Description of a new species of Ituglanis (Siluriformes: Trichomycteridae) from Serra dos Carajás, rio Tocantins basin. Neotrop. Ichthyol 10, 547-554.

Xia, X., Xie, Z., Salemi, M., Chen, L., Wang, Y., 2003. An index of substitution saturation and its application. Mol. Phylogenet. Evol. 26 (1), 1-7.

Xia, X., Lemey, P., 2009. Assessing substitution saturation with DAMBE. In: Lemey, P., Salemi, M., Vandamme, A.M. (Eds.), The Phylogenetic Handbook: A Practical Approach to DNA and Protein Phylogeny. Second ed. University Press, Cambridge, pp. 615-630.

Xia, X., 2013. DAMBE5: a comprehensive software package for data analysis in molecular biology and evolution. Mol. Phylogenet. Evol. 30 (7), 1720-1728. 